\title{
Problem-Based Workshop For Improving Product Diversification Of The Kolang-Kaling Process
}

\author{
${ }^{1 *}$ Desnita, ${ }^{2}$ Iryani, ${ }^{3}$ Yenni Darvina \\ ${ }^{1}$ Fakultas Matematika dan Ilmu Pengetahuan Alam, Universitas Negeri Padang, Indonesia \\ Email: iryaniachmad62@gmail.com²
}

\begin{abstract}
Tanah Datar Regency is known as one of the abundant fruit-producing areas of Kolang-Kaling. According to an interview by the PKM team with one of the heads of the women farmer groups, it was revealed that every week as many as 3 tons of Kolang-kaling fruit can be harvested. However, they only process $10 \%$ traditionally (boiled, peeled, and sold). The community does not have sufficient competence to apply technology in processing these plantation products into ready-to-eat food. As a result of the agreement with the two Cempaka Mekar and Teratai Women's Farmer Groups, also with the approval of the village head, a community partnership activity was agreed upon for these two farmer groups. With the aim of increasing the competence of women who are the target of activities in the application of technology for processing kolang-kaling fruit . Increasing competence is expected to have an impact on the welfare of the target community. In order to achieve the objectives, a problembased workshop model was chosen, where the workshop activities were conducted based on partner problems, with an andragogical approach.
\end{abstract}

Keywords: Kolang kaling, problem-based workshops, application of science and technology

\begin{abstract}
Abstrak
Kabupaten Tanah Datar dikenal sebagai salah satu daerah penghasil buah kolang kaling yang cukup berlimpah. Menurut wawancara tim PKM dengan salah satu ketua kelompok wanita tani, terungkap bahwa setiap minggu bisa dipanen buah kolang kaling sebanyak 3 ton. Namun hanya $10 \%$ saja yang mereka olah secara tradisional (direbus, dikupas, dan dijual). Masyarakat tidak memiliki kompetensi yang cukup untuk mnerapkan teknologi dalam pengolahan hasil perkebunan tersebut menjadi makanan siap saji. Hasil kesepakatan dengan dua Kelompok Wanita Tani Cempaka Mekar dan Teratai, juga atas persetujuan Wali Nagari setempat, disepakati kegiatan kemitraan masyarakat untuk kedua kelompok tani ini dengan tim PKM FMIPA UNP. Tujuan dari kegiatan ini adalah untuk peningkatan kompetensi kaum wanita yang menjadi sasaran kegiatan dalam penerapan teknologi pengolahan buah kolang-kaling. Dengan bertambahnya kompetensi diharapkan berdampak terhadap kesejahteraan masyarakat sasaran. Untk mencapai tujuan dipilih model workshop berbasis masalah, dimana kegiatan workshop dilakukan berbasis permasalahan mitra, dengan pendekatan pedagogis.
\end{abstract}

Kata Kunci: Kolang kaling, workshop berbasis masalah, penerapan IPTEK

\section{ANALISIS SITUASI}

Kelompok tani aren Teratai dan Cempaka Mekar adalah dua kelompok tani yang sudah turun temurun mengolah berbagai hasil panen dari pohon Aren, seperti air nira, buah kolang kaling, ijuk, dan pohon yang sudah tua. Air nira diolah menjadi gula merah atau palm suger, gula semut dan minuman fermentasi. Buah nya yang disebut buah kolang kaling direbus dan diolah lagi menjadi penganan.,sedangkan untuk pohon dan ijuk hampir tidak diolah oleh kedua kelompok tani ini karena pengolahan yang sulit dan harga sangat murah.

Semua air nira yang dipanen, sekitar 10-20 liter per hari sudah mampu mereka olah menjadi gula aren, gula semut, dan minuman fermentasi yang menyegarkan. Namun kelompok tani ini tidak mampu mengolah buah kolang kaling menjadi makanan jadi yang siap dikosumsi, kecuali kolak yang dibuat hanya di bulan Ramadhan. Menurut ketua kelompok tani ini mereka hanya memiliki keterampilan merebus dan mengupas secara tradisional. Sehingga hasil ladang yang berlimpah, sekitar 3 ton per minggu hanya sekitar $300 \mathrm{~kg}$ yang mampu mereka rebus dan laku dijual, (Ernalis dan 
Mailis, 2019). Ketika ditanya kenapa, menurut beliau konsumen tidak terlalu tertarik dengan buah kolang kaling yang tidak siap dikosumsi. Sisa yang 2,7 ton hasil panen mereka jual dengan harga murah (75 ribu per tandan yang bobotnya sekitar 100-150 kg). Sehingga potensi panen yang begitu berlimpah tidak bisa mereka nikmati.

Setiap tandan berisi 100-150 kg buah kolang kaling, hasil bersih setelah direbus dan dikupas sekitar 40-60 kg, sangat tergantung pada kondisi buah dan kematangan saat dipanen. Setiap kg dijual dengan harg Rp. 7.000,-. Bila dijumlahkan dengan penghasilan mereka dari air nira, per bulan setiap anggota hanya mendapatkan sekitar Rp. 1.100.000,- menurut mereka penghasilan tersebut tidak mencukupi untuk hidup satu keluarga. Bila buah kolang kaling mereka diolah, misalnya menjadi manisan, maka harga per kg di pasaran saat ini mencapai Rp. 95.000,-, jadi bisa mencapai lebih dari 10 kali nilai mentahnya. Ketika tim PKM bertanya kenapa mereka hanya mengolah $10 \%$ saja, menurut kedua kelompok tersebut, karena sejumlah itu yang bisa mereka jual. Pembeli menginginkan hasil olahannya, namun mereka tidak mampu mengolah lebih lanjut. Menurut pengakuan ketua kelompok tersebut, sisa yang $90 \%$ mereka jual tanpa diolah sama sekali. Tentu saja penjualan tersebut dengan harga yang sangat murah, sekitar Rp. 75.000,- sampai Rp. 100.000,- per tandan.

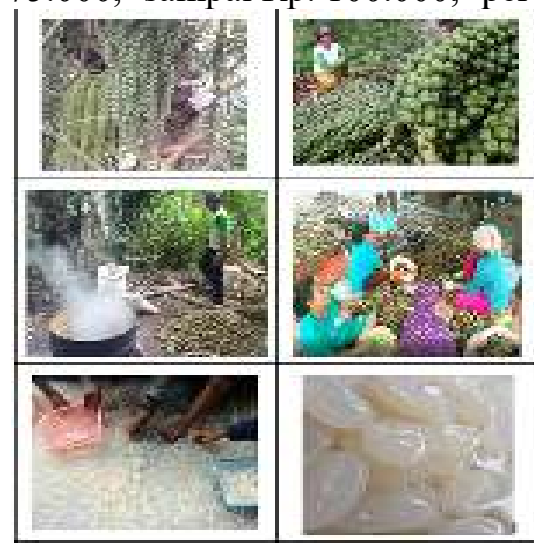

Gambar 1. Kondisi Mitra sebelum Kegiatan PKM

Gambar di atas memperlihatkan bahwa disamping pengolahan yang sangat tradisional, di dalam prosesnya mereka tidak memperhatikan faktor kesehatan dan keselamatan kerja, tidak memperhatikan kebersihan, dan juga tidak ramah lingkungan. Terlihat dengan jelas buah yang sudah direbus tergeletak begitu saja di tanah dan kulitnya dibuang di sekitar lokasi pengolahan. Menurut pengakuan kedua ketua kelompok tani ini, mereka sudah pernah mendapatkan pendidikan mengolah buah kolang kaling menjadi kerupuk, namun mereka tidak bisa berhasil membuatnya. Sebelum tim pengabdian bertemu dengan kelompok tani ini, mereka pernah diminta untuk mengeringkan buah tersebut, atau diolah lebih lanjut menjadi makanan siap dikosumsi, namun mereka tidak mampu memenuhi permintaan tersebut karena minimnya keterampilan mengolahnya. Bahan baku kolang kaling yang dihasilkan di lokasi pengabdian ini sangat berlimpah ( 3 ton per bulan), tapi belum mampu mensejahterakan petani. karena rendahnya keterampilan mengolah hasil panen. Pada hal makanan olahan kolang kaling sangat diminati oleh masyarakat, karena berbagai alasan seperti kesehatan dan kandungan gizi yang tinggi.

Kandungan serat dan mineral dalam setiap 100 gram kolang-kaling yaitu energi 27 kkal, protein 0,4 gram, lemak 0,2 gram, karbohidrat 6 gram, serat 1,6 gram, kalsium $91 \mathrm{mg}$, fosfor $243 \mathrm{mg}$ dan zat besi 0,5 mg serta kadar air mencapai 94\%; (Purwati dan Tutik Nugrahini, 2018). Kolangkaling memiliki kadar air sangat tinggi, mencapai 93,8 persen dalam setiap 100 gram. Kolang-kaling juga mengandung 0,69 gram protein, serta kadar abu sekitar satu gram dan serat kasar 0,95 gram, dan mengandung 52,9 persen karbohidrat, pada umumnya berbentuk polisakarida galaktomanan. Galaktomanan ini sudah banyak digunakan sebagai pengental, stabilizer emulsi, aditif pada industri pangan dan obat-obatan, menurut (Reid, Edwards, Mikkonen, 2009).

Dengan kandungan gizi yang tinggi tersebut buah kolang kaling merupakan bahan makanan yang banyak diminati masyarakat. kolang kaling dari buah betina yang sudah masak dan tepung aren untuk bahan kue, roti dan biscuit, yang berasal dari pengolahan bagian empelur batang tanaman (Alam dan Baco, 2004. Maliangkay et al., 2004). Buah kolang kaling dapat diolah menjadi Setup pisang kolang kaaling, sop kolang kaling, dana manisaan kolang kaling (Purwati dan Tutik Nugrahini, 
Journal Humanities: Jurnal Pengabdian kepada Masyarakat

Volume 1, Nomor 2, Bulan Desember, 2020.

E - ISSN 2715-5471

Doi: https://doi.org/10.24036/jha.02.01.2020.10

2018). Kolang kaling dengan tingkat kematangan yang lunak memiliki kadar serat yang tinggi yaitu $14.03 \%$. memiliki potensi yang besar untuk dijadikadikan sebagai olahan minuman dan makanan. Kolang kaling yang lunak juga mengandung kadar pati yang tinggi yaitu $74.58 \%$. Kandungan pati pada kolang kaling dapat memberikan rasa kenyang dan menghentikan nafsu makan, sehingga cocok dikonsumsi sebagai makanan diet, (Syafiruddin H dan kawan-kawan, 2018).

Pengolahan buah kolang kaling menjadi makanan seperti manisan kolang kaling, bisa meningkatkan penghasilan masyarakat lebih lima kali lipat atau lebih. Menurut survey pasar yang dilakukan oleh peneliti, harga manisan kolang kaling yang sudah dikemas saat ini mencapai Rp. 93.000,-. Jadi pengolahan buah kolang kaling oleh masyarakat sasaran diprediksi mampu menjadikan kelompok mereka menjadi kelompok pengusaha kecil bahkan menengah, bukan lagi petani tradisional. Tentunya ini secara langsung berdampak terhadap kesejahteraan mereka. Oleh sebab itu dibutuhkan keterampilan hidup (life skill).

Mengacu pada analisis situasi yang sudah dilakukan kedua kelompok tani ini mengalami banyak permasalahan dalam mengolah buah kolang kaling. Pertama, Rendahnya pengetahuan masyarakat mitra mengolah buah kolang kaling menjadi bahan makanan siap kosumsi dan bahan makanan setengah jadi yang berwawasan lingkungan, sesuai permintaan mitra dagang kelompok tani. Kedua, Rendahnya keterampilan masyarakat mitra mengolah buah kolang kaling menjadi bahan makanan siap kosumsi dan bahan makanan setengah jadi yang berwawasan lingkungan berwawasan lingkungan, Mengacu pada latar belakang, potensi, dan permaalahan masyarakat mitra PKM ini, maka tujuan dari kegiatan PKM ini adalah "meningkatkan kompetensi anggota kelompok Wanita Tani menerapkan teknologi dalam pengolahan buah kolang kaling menjadi produk makanan siap saji" pada kegiatan ini dibatasi pada keteramilan menerapkan teknologi untuk mengolah buah kolang kaling menjadi selai nagaling, cocktail kolang kaling, dan sukade kolang kalaing.

\section{SOLUSI DAN TARGET}

Permasalahan pertama dari masyarakat sasaran diselesaikan dengan cara sharing pengetahuan tentang berbagai produk olahan buah kolang kaling, dilatih melakukan pencarian informasi terkait pengolahan buah kolang kaling di dunia maya. Menyediakan bahan ajar berupa modul yang berisi pengetahuan tentang buah kolang kaling komposisi dan manfaatnya, serta pengolahan buah kolang kaling menjadi SELAI NAGALING, COCTAIL NAGALING, dan SUKADE KOLANG KALING, yang ditulis oleh tim pengabdi. Nagaling merupakan singkatan dari naga dan kolang kaling. Selai dibuat dengan menggabungkan kolang kaling dengan sirup buah naga produksi POLITANI Negeri Payakumbuh, dan pencerah warna menggunakan produk pewarna herbal yang memenuhi standar buatan tim pengabdian.

Buku sudah diberikan kepada masyarakat sasaran 2 minggu sebelum kegiatan latihan keterampilan dilaksanakan. Pada saat penyerahan buku oleh tim pengabdi, dialkukan diskusi untuk menyamakan persepsi dan menyepakati kegiatan pelaksanaan latihan keterampilan. Supaya frekuensi latihan lebih banyak dan masyarakaat mencapai tingkat mahir, maka kedua kelompok ini akan mengirimkan perwakilan sebanyak 4-5 orang untuk dilatih dan siap menjadi tutor sebaya bagi teman di kelompok masing-masing. Pada saat ini juga disepakati tempat dan waktu kegiatan. Tuliskan semua solusi yang ditawarkan untuk menyelesaikan permasalahan yang dihadapi dan arget luaran kegiatan pengabdian.

Solusi permasalahan kedua yaitu dengan melakukan Kegiatan terdiri dari beberapa tahapan berikut: (1) mengecek pengetahuan peserta setelah membaca buku dan mengecek apakah ada diantara peserta yang sudah mencoba sendiri latihan keterampilan setelah membaca buku. (2) simulasi pembuatan makanan olahan kolang kaling oleh tim dan disaksikan oleh seluruh peserta. Makanan yang dibuat seperti yang telah disampaikaan pada solusi masalah 1. (3) mendiskusikan permasalahan mitra tentang proses pembuatan, bila mungkin saat mencoba secara mandiri mengalami kendala. (4) Mengkaji hasil yang dibuat untuk menemukan kekurangan dari apa yang sudah dibuat. (5) bila perlu mengulangi peragaan pembuatan. (6) memberi kesempatan kepada peserta untuk berlatih sendiri 
keterampilan mengolah buah kolang kaling menjadi aneka masakan tersebut, mengkaji proses dan hasil untuk menemukan permasalahaan dan kekurangan. (7) mengulangi latihan pada kesempatan berbeda sebanyak 4-6 kali, untuk mencapai kemahiran dalam membuat makanan olahan buah kolang kaling. Semuaa kegiatan ini dilakukan di lokasi pengabdian, melatih masyarakat sasaran membuat makanan-makanan tersebut sampai mahir membuat dengan proses dan hasil sesuai dengan apa yang sudah ditetapkan oleh tim pengabdi. Kegiatan ini berlangsung 6-8 kali pertemuan. (8) melakukan analisis laboratorium untuk mengetahui kandungan gizi (kandngan air, mineral, kalori, lemak, protein, dan vitamin) yang terdapat pada makanan hasil olahan kolang kaling yang sudah dibuat dengan cara dan hasil sesuai target. (9) melakukan tes pembuatan makanan olahan, untuk melihat peningkatan kompetensi masyarakat sasaran mengolah kolang kaling.

Luaran yang diharapkan dari hasil kegiatan ini adalah peningkatan kemampuan/keterampilan Kelompok tani aren Teratai dan Kelompok Wanita Tani Cepaka Mekar mengolah buah kolang- kaling serta bernilai ekonomis yang dapat dipasarkan. Selain itu, luaran dari kegiatan ini adalah suatu produk berupa draft jurnal pengabdian masyarakat ber-ISSN.

\section{METODE PELAKSANAAN}

Metode yang diterapkan dalam pendampingan berbasis potensi dan masalah masyaraakat sasaran untuk kelompok tani aren TERATAI di Jorong Pakan Sinayan, Nagari Batu Bulek, Kecamatan Lintau Buo Utara dan Kelompok Wanita Tani CEMPAKA MEKAR Kabupaten Tanah Datar, SUMBAR ini, menerapkan konsep pendidikan andragogis dengan pendekatan partisipatif, yang mengedepankan prinsip dari, bagi, dan untuk masyarakat sasaran atau berbasis masalah. Tim pengabdian menempatkan diri sebagai kolega yang menjadi motivator, fasilitator, mediator, dan katalisator bagi msyarakat sasaran dalam mencapai tujuan dan harapan yang telah disampaikan kepada tim pengabdian

\section{PELAKSANAAN KEGIATAN}

Karena pelaksanaan kegiatan PKM ini di tengah pandemic covic19, maka tim menerapkan standar yang sudah ditetapkan. Jumlah peserta dibatasai, supaya tidak terlalu banyak kerumunan orang di lokasi workshop. Pembatasan anggota diserahkan kepada ketua kelompok masing-masing. Dari kelompok cempaka mekar mengirim anggota tetap sebanyak 5 orang tambah 1 ketua kelompok. Sedangkan kelompok teratai mengirimkan 10 orang dengan ketua kelompok mereka. Namun yang mengikuti 2 kali tes ( pre-test dan post-test ) hanya 10 orang.

Pelaksanaan kegiatan PKM di nigari Batu Bulek Kecamatan Lintau Buo Utara Kabupaten Tanah Datar ini, terasa berbeda dengan kegiatan PKM yang sudah dilakukan oleh tim PKM FMIPA UNP sebelumnya. Berikut catatan penting tim, Kegiatan ini mendapatkan dukungan moral penuh dari pemerintahan jorong, nagarai, dan PPL setempat. Mulai dari sosialisasi kegiatan, perencanaan, sampai pelaksanaan ketua KWT didampingi oleh PPL. Setiap kegiatan yang direncanakan dan dilakukan didukung oleh tiga komponen tersebut. Pembukaan PKM dilaksanakan di Balai Adat Nagari Batu Bulek atas izin Wali Nagari dan persiapan tempat dilakukan oleh kepala jorong pakan Sanayan. Kegiatan pembukaan dihadiri oleh Wali Nagari, Sekretaris Nagari, Kepala Jorong, dan PPL. Dua hari kegiatan workshop minggu pertama tanggal 12-13 September 2020, dilaksanakan di Balai latihan Silat Jorong Pakan Sanayan. Kegiatan ini atas bantuan tenaga dan moral dari Kepala Jorong Pakan Sanayan, tempat KWT Teratai berdomisili. 


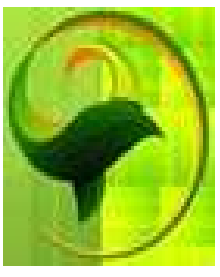

Journal Humanities: Jurnal Pengabdian kepada Masyarakat Volume 1, Nomor 2, Bulan Desember, 2020.

E - ISSN 2715-5471

Doi: https://doi.org/10.24036/jha.02.01.2020.10

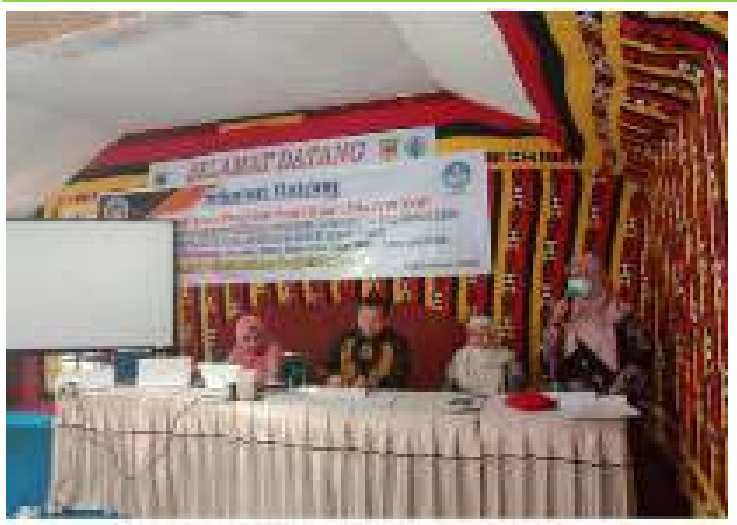

Gambar 2. Sambutan Wali Nagari Batu Bulek

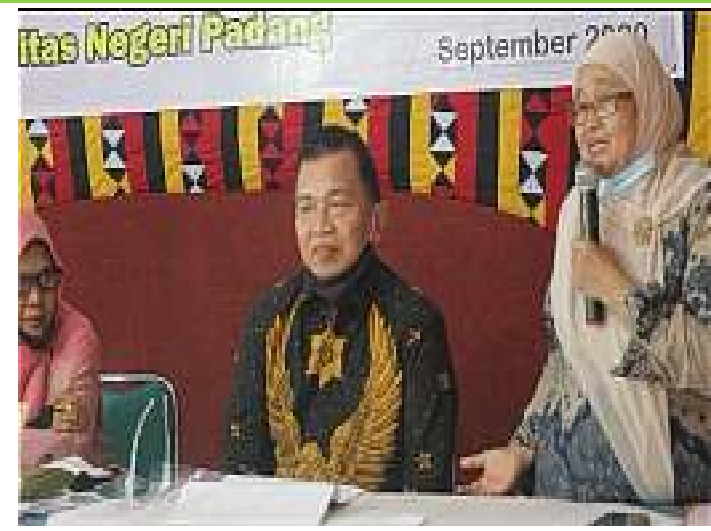

Gambar 3. Sambutan Ketua PKM

Dua hari kegiatanpada Minggu kedua tanggal 19-20 September 2020 dilaksanakan di Balai Pemuda dan Pusat kegiatan Jorong Ladang Laweh. Ini juga atas bantuan moril dan tenaga dari Kepala Jorong Ladang Laweh, tempat KWT Cempaka Mekar berdomisili. Antusias yang luar biasa dari peserta kegiatan PKM terlihat dari pertisipasi dan kedisiplinan peserta. Setelah acara pembukaan di Balai Adat Nagari, mereka langsung ke lokasi latihan tanpa dikomando. Karena mereka sudah menerima modul sebagai panduan kegiatan, peserta langsung membersihan dan memotong buahbuahan yang sudah disediakan sesuai petunjuk pada modul. Hari pertama setelah pembukaan kegiatan berlangsung sampai jam 6 sore non stop. Tiga hari sisanya kegiatan dilaksanakan dari jam 8 pagi sampai jam jam 6 sore. Semua peserta bersemangat berlatih dan muncul kreativitasnya.

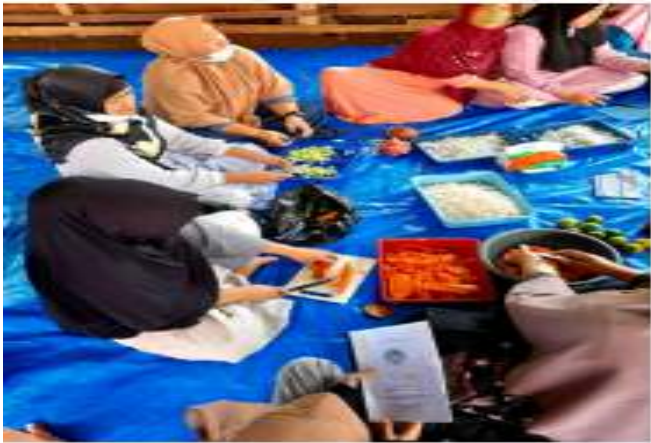

Gambar 5. Foto kegiatan Hari pertama

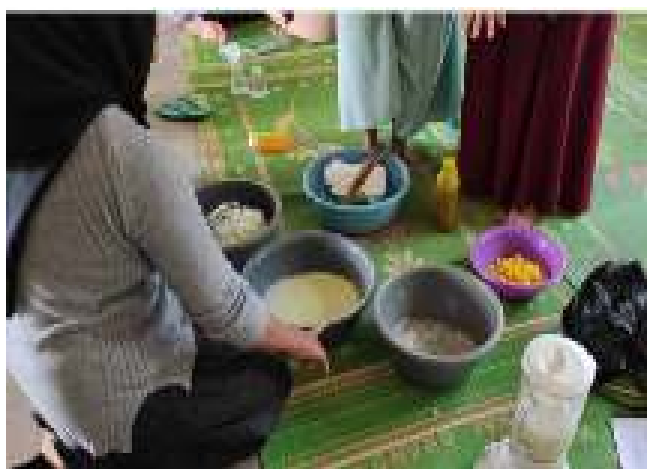

Gambar 7. Foto kegiatan Hari Ketiga

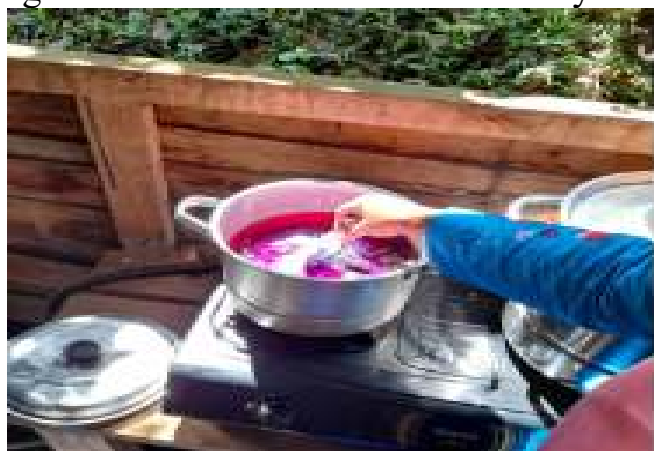

Gambar 6. Foto kegiatan Hari Kedua

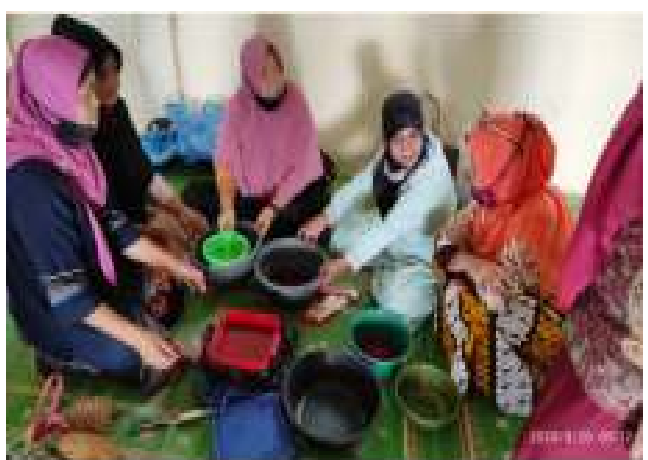

Gambar 8. Foto kegiatan Hari Keempat

Ketika mereka diajarkan keterampilan tambahan membuat sirup buah naga dari air hasil blanching buah naga, merka semakin bersemangat. Kreativitas dari peserta muncul ketika ada sisa buah nanas dan buah naga dari pembuatan cocktail. Mereka bertanya apakah ini bisa dibuat menjadi selai nasling. Tim memberikan tantangan kepada mereka, namun mengarahkan dengan 
menyampaikan perbandingan atau komposisi gula,nanas, dan buah kolang kaling. Jadilah mereka mendapatkan keterampilan tambahan kedua, yaitu selai nasling. Salah satu kegiatan Pada pertemuan hari keempat adalah penyaringan buah kolang kaling dari cairan manisan, penirisan, pemotongan, dan pengeringan sukade. Didapat residu brupa air gula penyaringan sukade dari manisan kolang kaling. Tim hanya menginformasikan kalau air gulanya jangan dibuang, itu dapat dimanfaatkan sebagai pembuat pudding atau makanan lainnya.

\section{HASIL DAN PEMBAHASAN}

Dalam pelaksanaan pengabdian dilakukan pembagian lokasi, dimanatanggal 12-13 September kegiatan workshop dilaksanakan di desa Pakan Sanayan, sedangkan tanggal 19 dan 20 September kegiatan workshop dilangsungkan di Jorong Ladang Laweh, Nagari Batu Bulek, Kecamatan Lintau Buo Utara, Kabupaten Tanah Datar, Sumatera Barat ini. Khalayak mitra sangat mau dan antusias dalam menerima ilmu dari pengabdi, tidak terlihat kendala yang berarti. Berikut hasil analisis uji kuisioner dapat dilihat pada 9.

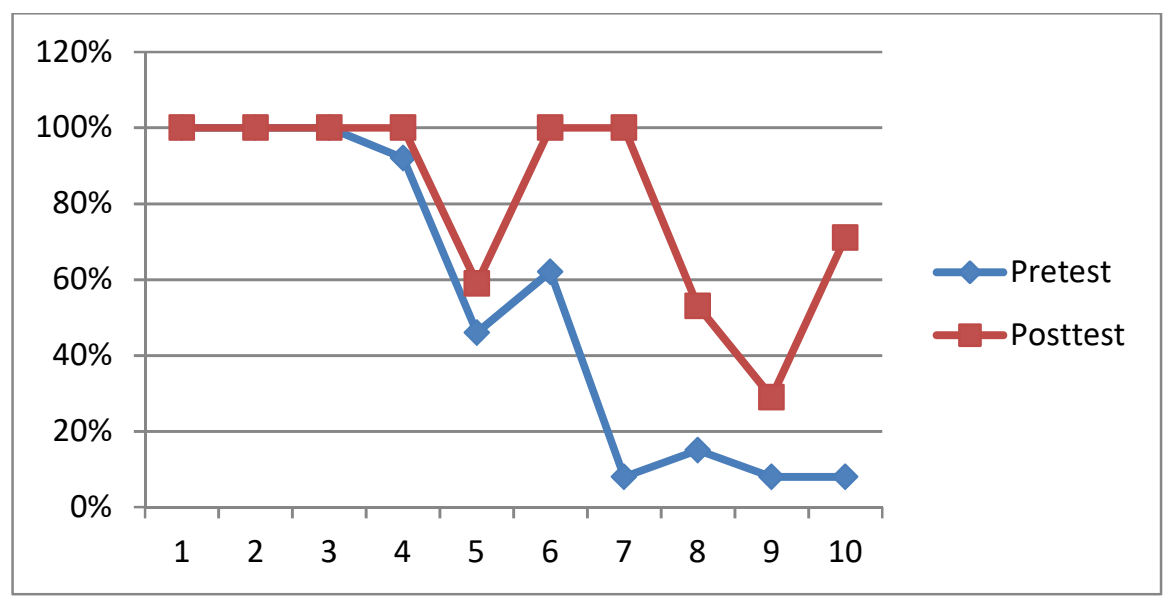

Gambar 9. Grafik analisis kuisioner

Berdasarkan hasil analisis kuisioner diatas dapat dilihat bahwa terjadi peningkatan sebelum dan sesudah dilakukannya workshop oleh pengebdi. Dari analisis tersebut dapat dilihat bahwa kegiatan yang dilakuakan oleh pengabdi berefek positif untuk meningkatkan kempuan masyarakat Jorong Ladang Laweh, Nagari Batu Bulek, Kecamatan Lintau Buo Utara, Kabupaten Tanah Datar, Sumatera Barat dalam mengolah hasil pertanian mereka yang berlimpah seperti buah Kolang-kaling. Dalam kegiatan ini pengabdi memjelaskan cara dan membimbing masayarakat secara langsung dalam mengolah kolang-kaling menjadi produk yang bernilai ekonomi tinggi . seperti, selai nagaling, coctail nagaling, dan sukade kolang kaling.

Buah kolang-kaling atau nama lainnya buah tab dikenal oleh peserta sejak tahun 1975. Peserta mengatahui daerahnya sebagai pengahasil buah kolang-kaling sejak 1972. Baisanya warga mengolah buah kolang-kaling dengan cara direbus atau dibuat menjadi kolak dan manisan. Setelah diadakan kegiatan ini peserta mendapat ilmu baru dalam mengolah buah kolang- kaling menjadi makan yang bernilai ekonomis tinggi. Seperti. selai nagaling, coctail nagaling, dan sukade kolang kaling. Peserta mengolah buah kolang kaling tersebut untuk dikonsumsi sendiri dan untuk dibisniskan. Namun perserta masih memiliki kendala dana dan pemasaranya.

Makanan hasil olahan yang dibuat oleh masyarakat sasaran juga sudah diuji di laboratorium, uji dilakukan terhadap kandungan gizi dari makanan olahan kolang-kaling tersebut. table 1 memperlihatkan kandungan gizi makanan olehan dimaksud

\begin{tabular}{|c|l|c|c|c|c|}
\hline \multicolumn{4}{|c|}{ Tabel 1 Kandungan gizi makanan olahan buah kolang-kaling } & Satuan \\
\hline \multirow{2}{*}{ No. } & Analisa & A & B & C & \\
\cline { 3 - 6 } & & 7,17 & 19,28 & 10,40 & $\mathrm{Mg} / 100 \mathrm{~g}$ \\
\hline 1 & Vitamin C & 5,08 & 7,70 & 6,64 & $\%$ \\
\hline 2 & Glukosa & &
\end{tabular}

Penerbit: Jurusan Pendidikan Olahraga, Fakultas Ilmu Keolahragaan, Univ. Negeri Padang 
Journal Humanities: Jurnal Pengabdian kepada Masyarakat Volume 1, Nomor 2, Bulan Desember, 2020. E - ISSN 2715-5471

Doi: https://doi.org/10.24036/jha.02.01.2020.10

\begin{tabular}{|c|l|c|c|c|c|}
\hline 3 & Sukrosa & 28,09 & 41,48 & 16,82 & $\%$ \\
\hline 4 & Total padatan & 36,05 & 61,00 & 42,99 & $\%$ \\
\hline 5 & PCA (totak Plate Count) & $1,1 \times 10^{5}$ & $3,1 \times 10^{6}$ & TBUD & Coloni/g \\
\hline 6 & APDA (Kapang Khamir) & $6,0 \times 10^{3}$ & $8,8 \times 10^{6}$ & $1,9 \times 10^{5}$ & Coloni/g \\
\hline 7 & EMBA (Total E.Colli) & 0 & $\begin{array}{c}7,9 \times 10^{3} \\
\text { (Non fecal) }\end{array}$ & $\begin{array}{c}3,0 \times 10^{5} \\
\text { (non fecal) }\end{array}$ & Coloni/g \\
\hline
\end{tabular}

Catatan: sampel A sirup nagaling

Sampel B selai nagaling komposisi 1

Sampel C selai nagaling komposisi 2

\section{KESIMPULAN}

berdasarkan apa yang sudah disampaikan pada hasil dapat disimpulkan bahwa Kegiatan PKM ini berhasil merubah keterampilan masyarakat sasaran mengolah buah kolang kaling dan Kegiatan PKM ini diterima masyarakat dengan antusias, dan berhasil memicu kreativitas mereka. Sebagai hasil kreativitas mereka adalah keterampilan membuat produk tambahan (diluar yang direncanakan), yaitu selai nasling. Dari hasil pemeriksaan laboratorium terhadap kandungan gizi dapat dikatakan bahwa makanan hasil olahan buah kolang kaling tersebut sehat dijadikan makanan penganan.

\section{PENGAKUAN}

Pengabdi mengucapkan terimakasih banyak pada masyarakat Jorong Ladang Laweh, Nagari Batu Bulek, Kecamatan Lintau Buo Utara, Kabupaten Tanah Datar, Sumatera Barat pengabdi kesempatan untuk melakukan kegiatan pengabdian kepada massyarakat ini.

\section{DAFTAR PUSTAKA}

Ernalis, 2019, Pengolahan air nira dan buah kolang kaling oleh Kelompok Tani TERATAI.

Purwati dan Tutik Nugrahini, 2018, Pemanfaatan Buah Kolang Kaling Dari Hasil Perkebunan Sebagai Pangan Fungsional, Jurnal Abdimas Mahakam, 2(1), hal. 24-33

Syafiruddin Harahap dan Kawan-kawan, 2018, Kadungan Nilai Gizi dari Kolang Kaling (Arenga Pinnata) Sebagai Sumber panagn Baru di tapanuli Bagian Selatan, Jurnal LPPM Universitas Graha Nusantara Padang Sidempuan, 2018, 9(1B), hal. 1-4.

Syafiruddin Harahap, Muhammad Nizar H Nasution2, Dini Puspita Y Nasution, Kandungan Nilai Gizi Kolang Kaling Dari Aren (Arenga Pinnata) Sebagai Sumber Pangan Baru Di Tapanuli Bagian Selatan, jurnal.ugn.ac.id, jurnal PPM, 8-Article Text-10-1-10-20180926.pdf.

Purwati dan Tutik Nugrahini, 2018, Pemanfaatan Buah Kolang Kaling Dari Hasil Perkebunan Sebagai Pangan Fungsional, 291-Article Text-477-1-10-20180501. 